\title{
Effect of Desertification on Some Selected Soil Properties in a Semi Arid Part of Northwestern Nigeria
}

\author{
Sheikh Danjuma Abubakar, Nathaniel Bayode Eniolorunda \\ Geography Department, Faculty of Social Sciences, Usmanu Danfodiyo University, Sokoto, Nigeria \\ Email: nathyk100@yahoo.com
}

Received 13 May 2016; accepted 22 July 2016; published 25 July 2016

Copyright (C) 2016 by authors and Scientific Research Publishing Inc.

This work is licensed under the Creative Commons Attribution International License (CC BY).

http://creativecommons.org/licenses/by/4.0/

(c) (i) Open Access

\begin{abstract}
Gudu, being a fringe local government area of Sokoto State of Nigeria, is in the heart of desertification zone of Nigeria where agriculture as the sole means of livelihood for the ever increasing population is endangered. The extent of the effect of desertification on the soil quality is unknown, and for sustainable livelihood, timely information on vegetation and soil resources of the area is of essence. It was therefore hypothesized that desertification has effect on the Soil Organic Carbon (SOC) and particle size. Objectives include assessment of vegetation condition of the area, vegetation change detection and identification of hotspots and assessment of soil properties in the hotspots. Biennial time series (1998 and 2014) of 1-km 10-day SPOT Normalized Difference Vegetation Index (NDVI) was subjected to Time Series Analysis (TSA). Vegetation change detection was carried out to isolate hotspots (improved and degraded areas) from which soil samples were taken. ANOVA was used to test for difference in the measured soil properties at $P<0.05$. Results show a general reduction vegetation cover, typical of a semi arid environment. SOC was generally low but higher in improved vegetation areas. While the degraded areas were purely sandy, improved vegetation was either Sand clay loam or Loamy sand, indicating a relationship between SOC and soil texture. It was concluded that desertification had effect on the selected soil properties in the study area. Embarkation on massive afforestation programme and protection of existing forest reserves coupled with environmental education for the farmers were recommended.
\end{abstract}

\section{Keywords}

Desertification, Soil Quality, NDVI, Soil Organic Carbon, Sokoto

\section{Introduction}

The United Nations Convention to Combat Desertification [1] defined desertification as land degradation in arid,

How to cite this paper: Abubakar, S.D. and Eniolorunda, N.B. (2016) Effect of Desertification on Some Selected Soil Properties in a Semi Arid Part of Northwestern Nigeria. Journal of Geoscience and Environment Protection, 4, 111-123. 
semiarid and dry sub humid areas resulting from climatic variations and anthropogenic activities. It is synonymous with land degradation in dry lands, manifesting in vegetation loss, water and wind erosion, salinization of irrigated and soil compaction [2]-[4]. It is also seen as a change in soil properties, vegetation or climate, which results in a persistent loss of ecosystem services that are fundamental to sustaining life [5].

Dry lands of the world are of critical concern as they cover over $41 \%$ of the surface of the earth with over 2 billion inhabitants [3]. The Africanarid and semiarid ecosystems are sensitive and dynamic, responding to fluctuations in climate and anthropogenic perturbations [6]. In the early 1970s, countries in the West African Sahel suffered prolonged drought years, caused by long-term rainfall fluctuations [6] [7]. The drought led to deaths of livestock and many inhabitants of the region [2]. Vast acreage of land which previously was productive in the northern Nigeria during the past three decades has been ravaged by desertification, resulting in farmers abandoning their farmlands due to loss of sustainable livelihood [5] [8]. It was affirmed that Nigeria loses 35,000 ha of land to desertification a year [9].

Soil quality and vegetation degradation in arid and semi-arid areas are the precursors and corollaries of desertification, and both are known to be highly correlated in most landscapes as their dynamics are being influenced by climate and anthropogenic activities [3] [10] [11]. Although recent studies have discovered some level of greening in the Sahel proving possible resuscitation of the ecosystem [12], a hallmark of desertification is its irreversibility or difficulty of rehabilitation of the affected area as the degradation process continues even when external environmental stresses, such as heavy overgrazing, are removed [13].

Desertification consequences are far-reaching, and combating the menace demands proactive approaches [14]. One of such approaches is to monitor the phenomenon via measuring land degradation and desertification processes [15] [16]. Satellite images have been widely used to monitor vegetation production for the purposes of mapping land degradation [11]. Studies have NOAA's operational environmental satellites and conventional data have been successfully used for drought detection and impact assessment in 20 countries [17]. The study discovered that drought can be detected weeks earlier before arrival. Similarly, the nature of vegetation trend across the Sahel was investigated [12]. The study successfully linked vegetation change (greening) of the study area to climate, land use management and migration. The footprint of vegetation dynamics in Kenya was traced using Advanced Very High Resolution Radiometer (AVHRR)/Moderate Imaging Spectro-radiometer (MODIS) NDVI data [18]. Results proved that vegetation trend monitoring with remotely sensed data can give accurate indication of climate change. A time series of 1-km SPOT Normalized Difference Vegetation Index (NDVI) was used to simulate the spatial trend of desertification in Sokoto and its environs, Nigeria [19]. Results showed the direction of desertification movement and that the inter-annual vegetation vigour exhibited a diminishing trend over the time series.

It has been affirmed that between $50 \%$ to $75 \%$ of the Border States of Nigeria are affected by desertification [9]. Gudu, being a fringe local government area of Sokoto State, is in the heart of desertification zone of Nigeria. Incidentally, it is one of the areas that benefitted from the afforestation scheme of the Colonial government. Today, the area, including the forest reserves, has largely been affected by desertification. Consequently, agriculture as the sole means of livelihood for the ever increasing population is endangered.

Desertification is expected to get worse in Nigeria with the growing population and climate change [9] [20]. Thus, for sustainable livelihood, timely information on vegetation and soil resources of the area is of essence. Remote sensing studies on desertification effect on the soil of the area are scanty in the literature. It is therefore hypothesized in this paper that desertification has effect on the Soil Organic Carbon (SOM) and particle size. Objectives include assessment of vegetation condition of the area, vegetation change detection and identification of hotspots and assessment of soil properties in the hotspots.

\section{Materials and Methods}

\subsection{Study Area}

The study area is located in Gudu Local Government Area of Sokoto State, which is situated in the extreme northwest of Nigeria and bordered by Niger Republic in North-West (Figure 1). The annual rainfall is around $500 \mathrm{~mm}$ experienced between June and September. The hot season peaks between March and April with a temperature of about $43^{\circ} \mathrm{C}$. The cold season which is accompanied by dust and sand laden winds is experienced between November and February, with the lowest temperature around $12^{\circ} \mathrm{C}$ [20] [21]. These climatic records have naturally conditioned the study area to Sudan savannah vegetation type composed primarily of shrubs and 
S. D. Abubakar, N. B. Eniolorunda

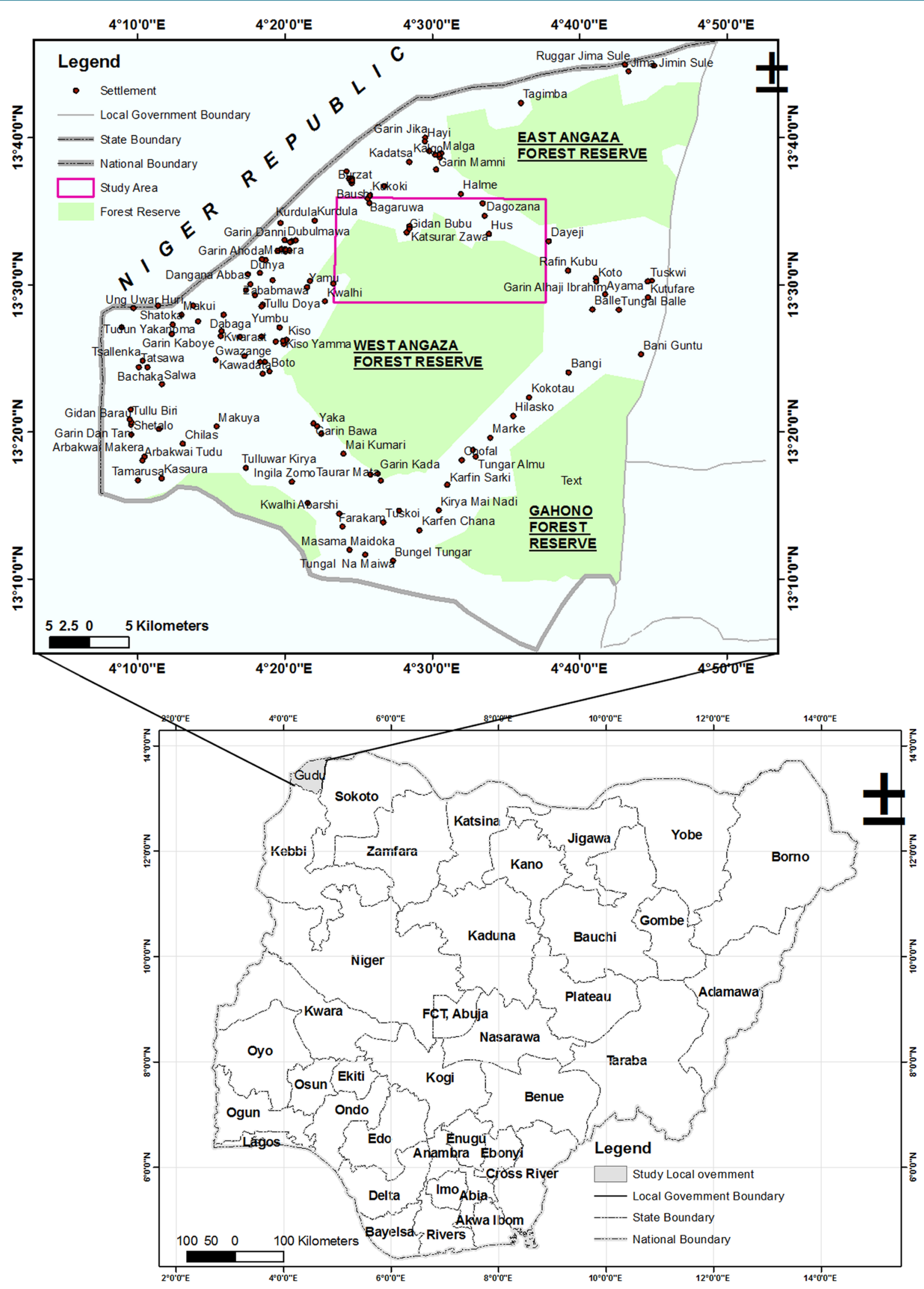

Figure 1. Map of the study area. 
grasses. However, a large part of it is forested, gazetted since the colonial period.

Two major geological formations characterize the area: basement complex and sedimentary rocks. The earlier comprises old volcanic and metamorphic rocks which are mainly granite and metasediments, while the latter is the Gwandu formation overlying basement rocks in the lullmeden basin, extending from Sokoto, Niger to Mali. The sedimentary rocks comprise sandstones and clays with a high potential for ground water. The soil is characterized by sandy topsoil of Aeolian origin while the subsoil is clayey, derived from marine deposit. The area is located in the popular Sokoto Plains characterised by monotonous planation of $300 \mathrm{~m}$ (above sea level) with isolated mesas.

Based on the estimate of 2006, the population of the area was put at 42,172 people. Rain-fed agriculture is the main source of livelihood, and crops grown are largely grains. This also goes with light grazing by the inhabitants but the area is largely exploited by nomadic livestock rearing across the borders. Agriculture, bush burning, fuel-wood extraction, among other activities are a threat to the already fragile vegetation and soil resources.

\subsection{Methods}

\section{Data Collection and Preparation}

Two types of data were used for this study: $1 \mathrm{~km}$ SPOT Normalized Difference Vegetation Index (NDVI) archived as 10-day composites (Figure 2) and data on soil organic carbon (SOC) and particle size of the area. The NDVI composites covering a period between April 1998 and December 2014 were freely downloaded via www.spot-vegetation.com in zipped format. The zipped SPOT NDVI composites were extracted after which the study area was sub-mapped from each scene. Maximum Value Composite (MVC) was used to recompose the ten-daily composites first into monthly composites and later into annual composites as the process has the capability of further correcting the inherent atmospheric effect [22]. Some composites could not be retrieved during data download due to technical failure; thus, annual composites were recomposed into biennial composites beginning from 1998 to 2014 (Figure 2).

Time Series Analysis was performed on the NDVI data series to determine the Principal Component (PC) and

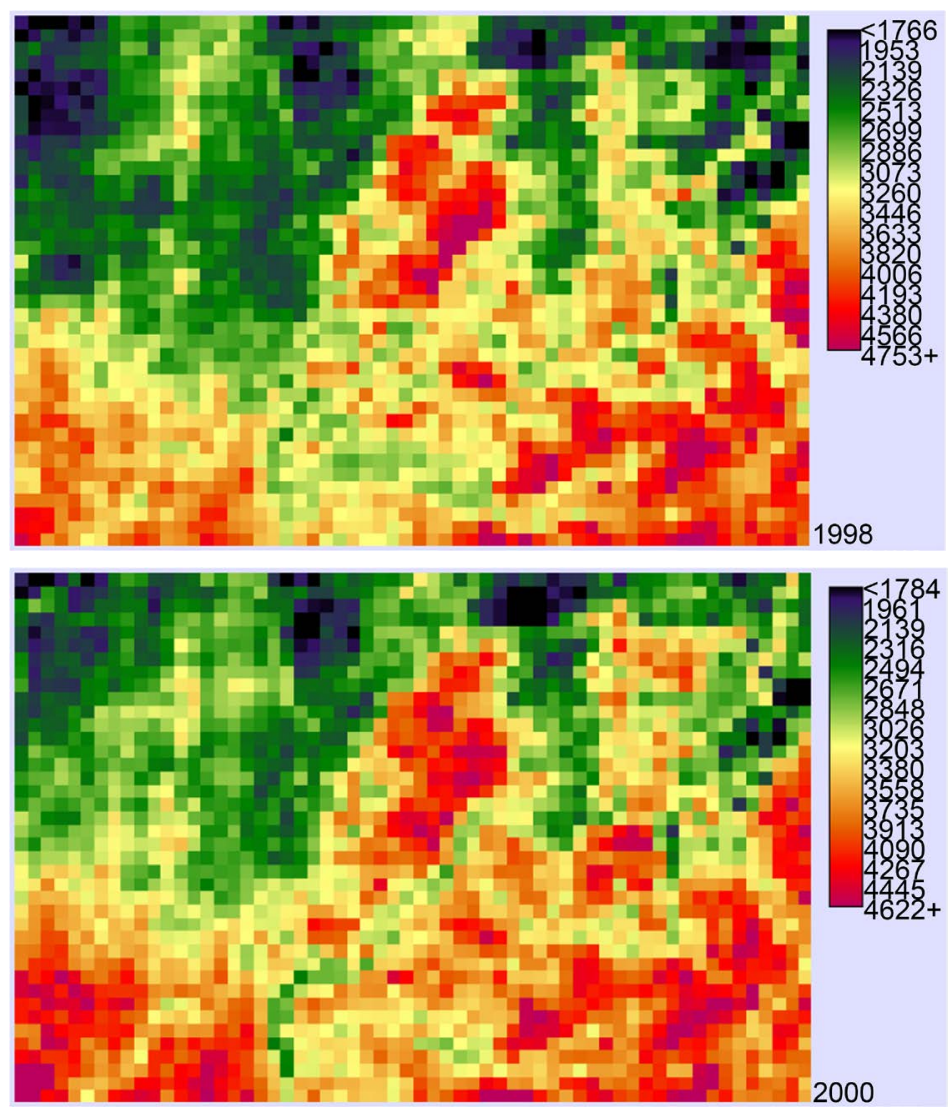



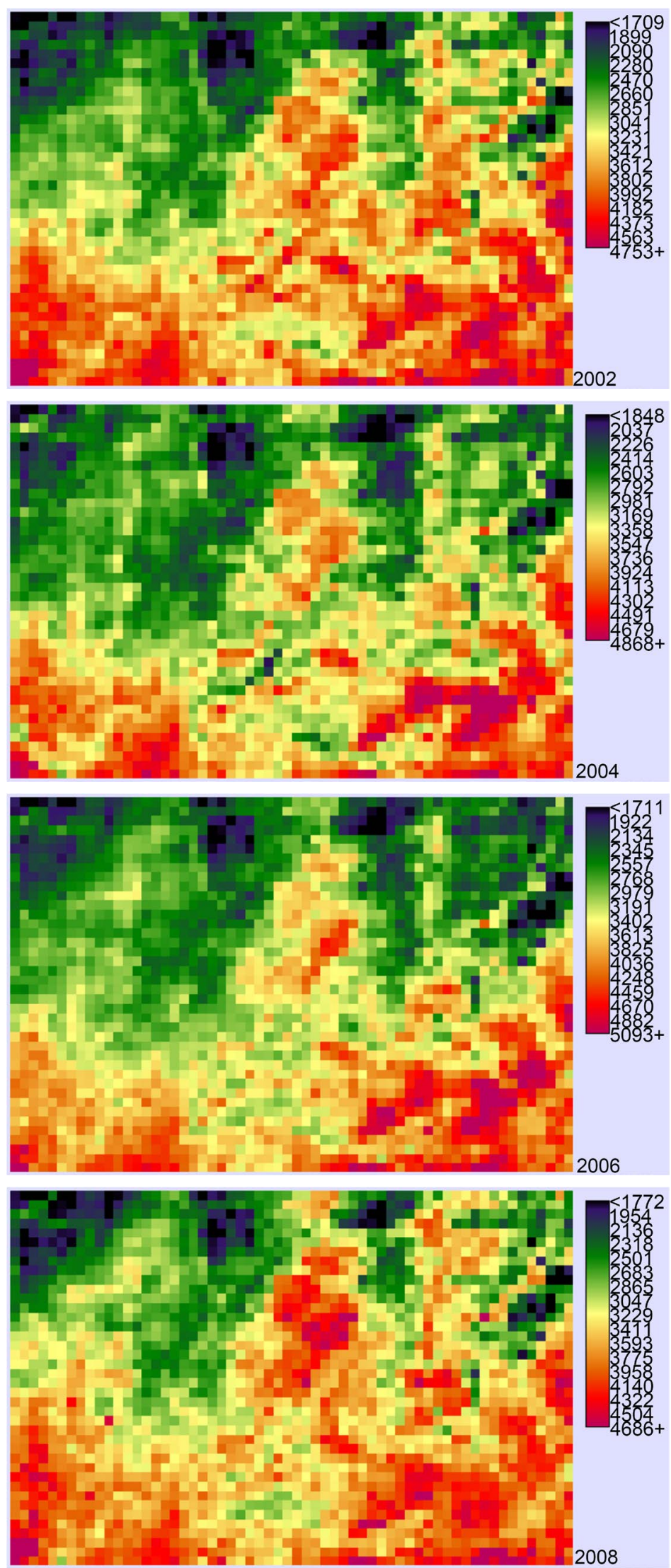

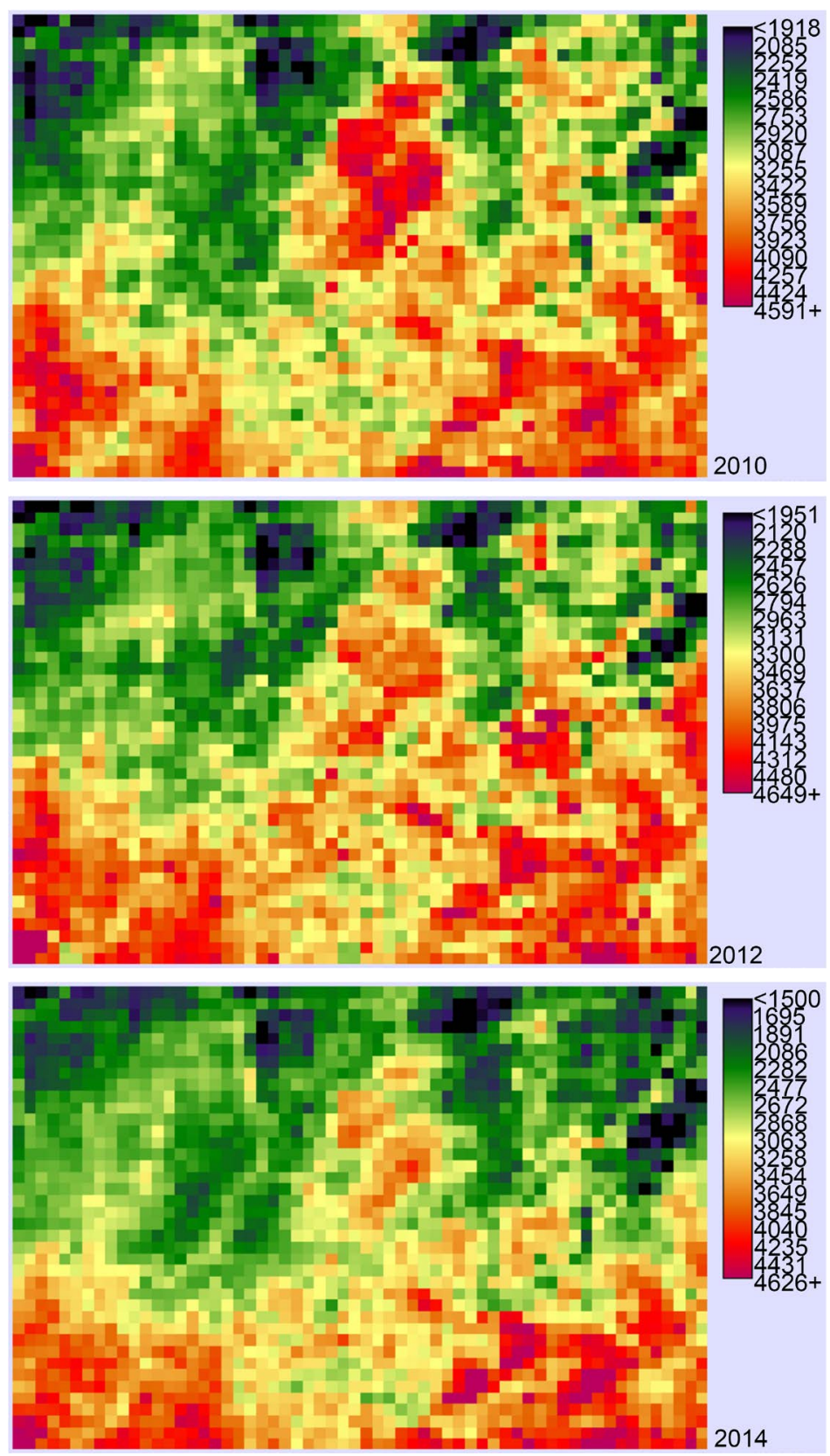

Figure 2. Biennial $1 \mathrm{~km}$ SPOT NDVI composites of the study area from 1998 to 2014.

slope coefficient of the Ordinary Least Squares (OLS) regression between the values of each pixel overtime. The PC presents the overall vegetation condition of the area across the time series indicating the trend of vegetation overtime [23] [24]. By this method, the condition of the vegetation over time can be inferred. The OLS regression is a generalized linear modelling technique that may be used to model a single response variable (vegetation) which has been recorded on at least an interval time scale [25]. It is represented mathematically as: $\boldsymbol{Y}=\boldsymbol{a}+\boldsymbol{b} \boldsymbol{X}$, where $\boldsymbol{Y}$ is the continuous response variable (vegetation), $\boldsymbol{X}$ is the continuous explanatory variable (time), $\boldsymbol{a}$ is the value of $\boldsymbol{Y}$ when $\boldsymbol{X}$ is zero, and $\boldsymbol{b}$ is the regression coefficient that describes the change in $\boldsymbol{Y}$ that is associated with a unit change in $\boldsymbol{X}$ [25]. The extreme values of OLS image (both positive and negative) represent the hotspots, and NDVI profiles were calculated at selected points of such areas to show vegetation trends. Two types of hotspots were marked in the area: areas of increasing greening and areas of vegetation degradation. This classification was carried out using three standard deviation to the mean: $=\mu \pm 3 \sigma$, where $\mu$ is the mean and $\sigma$ the stan- 
dard deviation. The area coverage of these categories were estimated and compared. Soil samples were taken from these hotspots, and soil properties were compared using independent t-test.

Data on soil was obtained by sampling using paired-plot approach [26] [27]. Four well-spaced pixels were purposively selected from areas of improved vegetation and four other pixels selected in the degraded areas such that the latter pixels were closely juxtaposed to those in the improved vegetation areas as indicated by the analysis performed on the NDVI images. Thus, eight pixels were sampled in all. In each pixel $\left(1 \mathrm{~km}^{2}\right)$, samples of soil were collected at four points and homogenized, out of which two handfuls were taken to the laboratory for analysis. Soil samples were taken to $30 \mathrm{~cm}$ depth using soil augers, and sampling was done at the time when biological activity was low [28], corresponding to the dry season.

Collected samples were bagged, labelled and transported to the laboratory for analysis. The samples were airdried for 48 hours, crushed and sieved with a 2-mm sieve. The samples were later used for testing for Soil Organic Carbon (SOC) and particle size (Sand, Silt and Clay).Particle size was analysed using the Bouyoucos hydrometer method [29] and classification was carried out using the textural triangle. The SOC was determined using the Walkley-Black method [30], while rating of SOC level was based on the scale in Table 1 [31].

\section{Data Analysis}

\subsection{Vegetation Condition of the Study Area}

The condition of vegetation describes the overall health of the vegetation as enhanced or constrained by environmental and anthropogenic factors. This was calculated using Time Series Analysis (TSA) to generate the Principal Component (PC) (Figure 3) which presents the average vegetation condition of the area [23]. In other words, it gives an illustration of the general spatio-temporal trend of the vegetation. Figure 4 shows the Loadings which describes the relationship between the PC and the time series images in Figure 2. The Loadings shows that the PC carries $92.32 \%$ of the information contents embedded in the time series, indicating a very high representativeness of the area. It also shows that there was a rising improvement in vegetation condition between the year 1998 and 2002, but the trend began to head down afterwards. This presents a general form of decline in vegetation which is likely a response to anthropogenic or climatic influence or both.

\subsection{Vegetation Change Hotspots}

The slope coefficient of the Ordinary Least Squares (OLS) image shows pixels with different values, representing different degrees of vegetation change. Negative values represent areas where degradation took place in the time

Table 1. Rating scales for SOC.
\begin{tabular}{ccccc|}
\hline Parameter & Low & Medium & High & Units \\
\hline OC & $<10$ & $10-15$ & $>15$ & $\mathrm{~g} / \mathrm{Kg}$ \\
\hline
\end{tabular}

Source: [31].

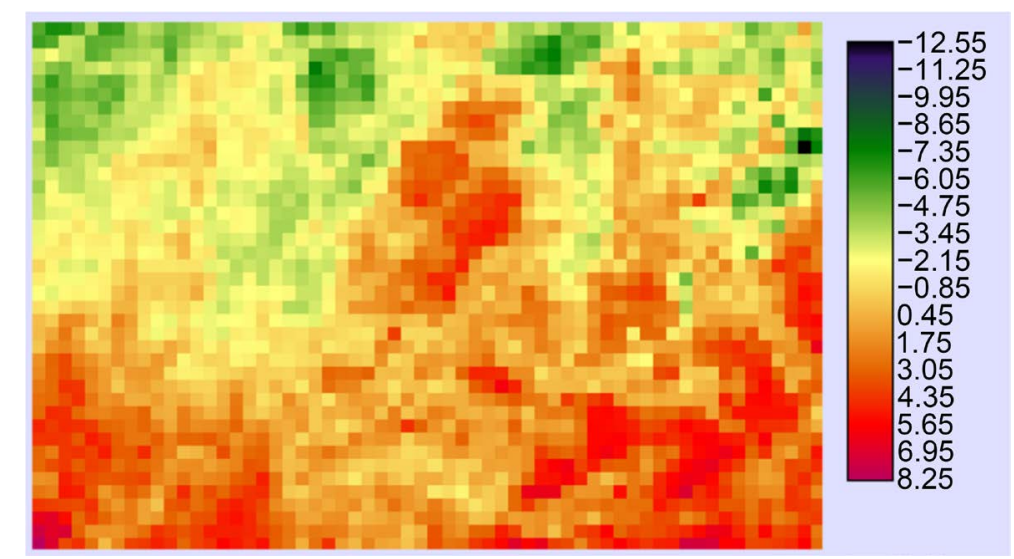

Figure 3. Principal component image showing the average vegetation condition of the area. 


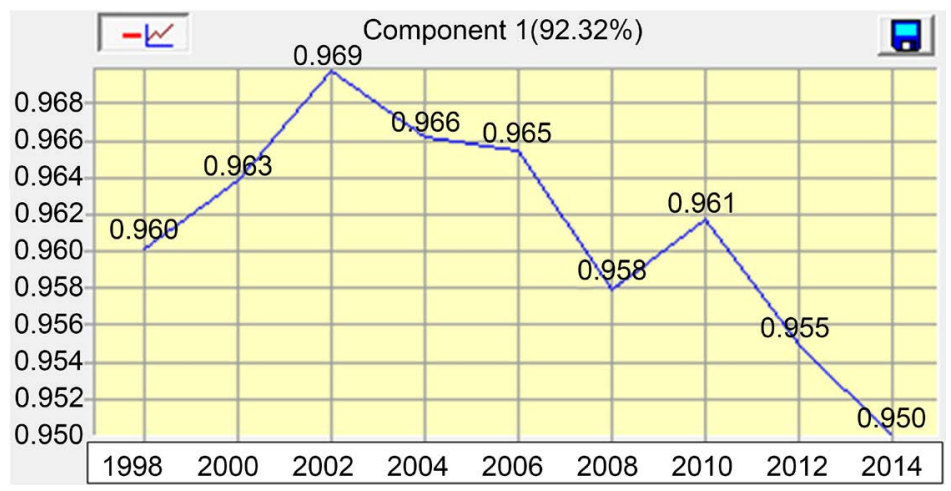

Figure 4. Component loadings showing a downward relationship between the PC and each time series image.

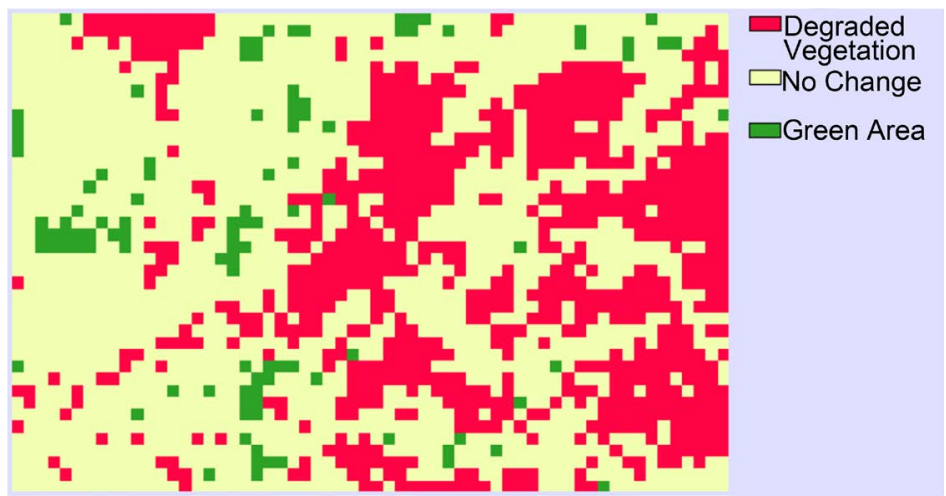

Figure 5. Reclassified OLS image showing clearly patches of change classes.

series while positive values show areas of vegetation improvement. Reclassification of these values using threestandard-deviation-to-the-mean algorithm (as the values are normally distributed) produced Figure 5. This map provides information on the spatial distribution of changes in vegetation. Green Areas are those places where vegetation appreciated overtime while No change areas are those places of minor vegetation variation. The degraded areas are places of negative vegetation change [23]. Both degraded and green areas (Figure 5) represent hotspots from which soil samples were collected.

Two profiles, one for each of the degraded and green areas, were computed (Figure 6 and Figure 7). Figure 6 shows increase in vegetation, while Figure 7 indicates a downward trend of vegetation change. Area estimates of Figure 5 show that the Green Areas cover 10,600 hectares while areas of No-change cover 148,800 hectares; about 80,600 hectares of vegetation are areas of vegetation degradation within the time period.

\subsection{Soil Property Status within the Hotspots}

Table 2 presents the ratings of soil properties at the selected hotspots, while Table 3 represents the descriptive summaries and ANOVA test result of the soil properties at the sampled hotspots. Although values are rated low in both hotspots classes (Table 2), it can be seen that SOC is higher in A (Improved vegetation) than in C, and the difference is statistically significant $(p<0.05)$ (Table 3$)$. Classification shows that the general texture in the degraded class is sand, while texture varies between Sandy clay loam and loamy sand in the green areas. The ANOVA test also indicates that that the textural differences are significant $(\mathrm{p}<0.05)$. These findings show that improved vegetation can positively affect SOC and texture.

\section{Discussion}

\subsection{Vegetation Condition of the Study Area}

Findings show that 92.32\% information was contained in the Principal Component (PC) image which shows a very high representativeness of the vegetation of the study area. PCs account for majority of the variability in a 
dataset, giving room for the description of information with few variables [32] [33]. PCA has been used to maximize change information in high variance components [34]. A PC of $72 \%$ information content was observed while assessing vegetation change in Nigeria with advanced very high resolution radiometer NDVI [35]. Further, a general form of decline in vegetation was discovered. It was argued that the north-western Sokoto which includes the study area is increasingly becoming desertified, manifesting a diminishing trend of interannual vegetation vigour [19].

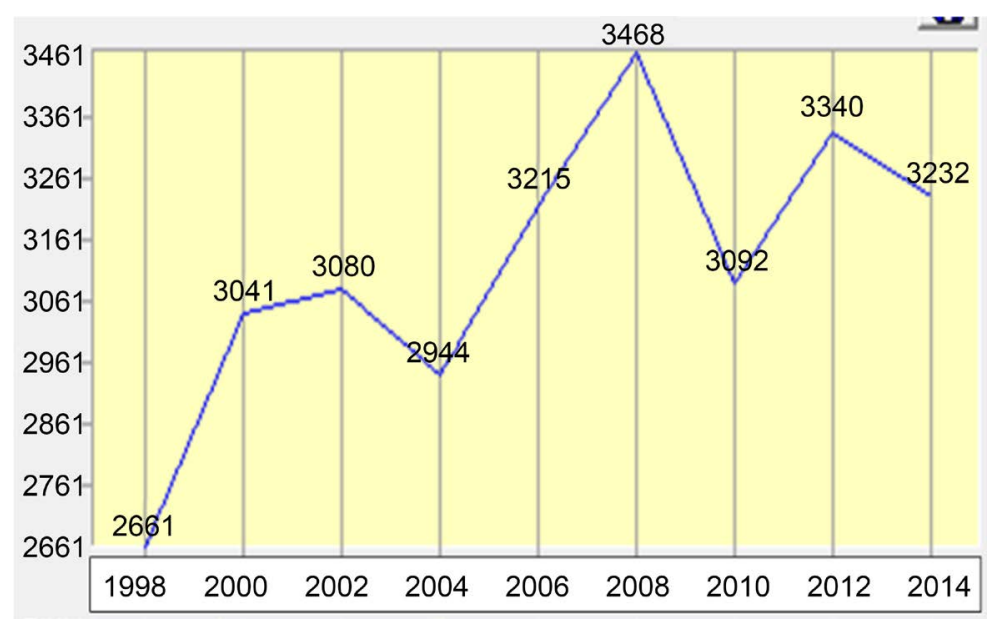

Figure 6. Profile of OSL at A.

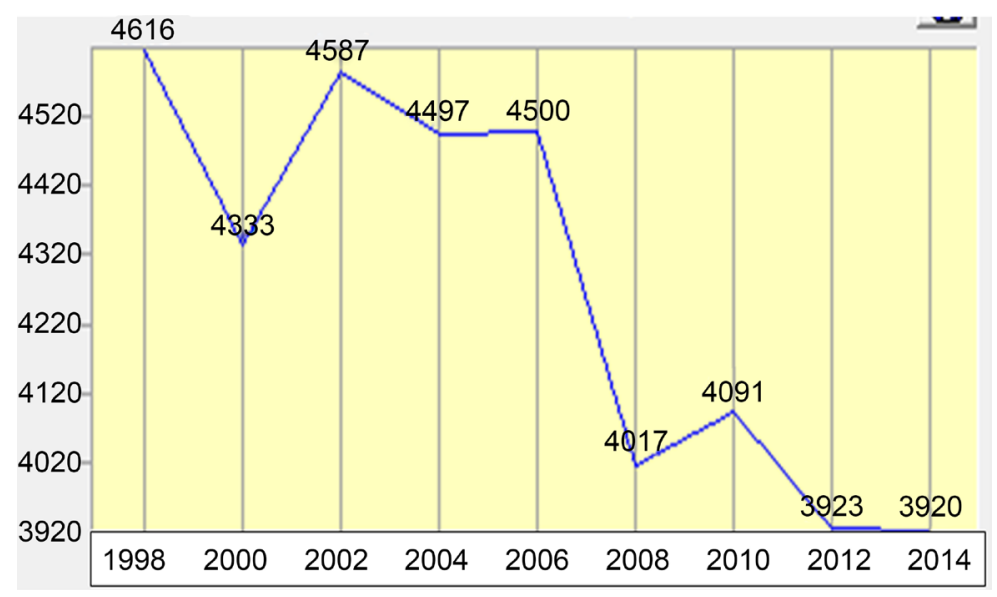

Figure 7. Profile of OSL at C.

Table 2. Ratings of SOC and particle size at the hotspots.

\begin{tabular}{ccccccc}
\hline Hotspots & SOC & SOC rating & Sand & Silt & Clay & Textural class \\
\hline C & 0.82 & Low & 89.00 & 6.70 & 4.30 & Sand \\
C & 0.59 & Low & 90.00 & 7.65 & 2.35 & Sand \\
C & 0.70 & Low & 90.00 & 7.65 & 2.35 & Sand \\
C & 0.65 & Low & 90.00 & 7.65 & 2.35 & Sand \\
$\mathbf{A}$ & 1.20 & Low & 61.76 & 16.67 & 21.57 & Sandy clay loam \\
$\mathbf{A}$ & 1.30 & Low & 76.39 & 9.80 & 13.81 & Loamy sand \\
$\mathbf{A}$ & 1.02 & Low & 64.71 & 14.71 & 20.58 & Sandy clay loam \\
$\mathbf{A}$ & 0.97 & Low & 80.29 & 9.12 & 10.59 & Loamy sand \\
\hline
\end{tabular}

Author's field work (2015). 
Table 3. Descriptive summary and ANOVA result.

\begin{tabular}{|c|c|c|c|c|c|}
\hline \multicolumn{2}{|c|}{ HSP } & \multirow{2}{*}{$\begin{array}{c}\text { SOC } \\
1.12\end{array}$} & \multirow{2}{*}{$\begin{array}{l}\text { Sand } \\
70.79\end{array}$} & \multirow{2}{*}{$\begin{array}{c}\text { Silt } \\
12.58\end{array}$} & \multirow{2}{*}{$\begin{array}{c}\text { Clay } \\
16.64\end{array}$} \\
\hline A & Mean & & & & \\
\hline & $\mathrm{N}$ & 4.00 & 4.00 & 4.00 & 4.00 \\
\hline & Std. deviation & 0.15 & 8.95 & 3.70 & 5.31 \\
\hline \multirow[t]{3}{*}{ C } & Mean & 0.69 & 89.75 & 7.41 & 2.84 \\
\hline & $\mathrm{N}$ & 4.00 & 4.00 & 4.00 & 4.00 \\
\hline & Std. deviation & 0.10 & 0.50 & 0.48 & 0.98 \\
\hline \multirow[t]{5}{*}{ Total } & Mean & 0.91 & 80.27 & 9.99 & 9.74 \\
\hline & $\mathrm{N}$ & 8.00 & 8.00 & 8.00 & 8.00 \\
\hline & Std. deviation & 0.26 & 11.71 & 3.68 & 8.18 \\
\hline & F-value & 22.47 & 17.91 & 7.68 & 26.18 \\
\hline & p-value & 0.003 & 0.005 & 0.032 & 0.002 \\
\hline
\end{tabular}

\subsection{Vegetation Change Detection}

Results also show that more areas exhibited vegetative changes than vegetation improvement. Between $50 \%$ to $75 \%$ of the Border States of Nigeria are reportedly affected by desertification [9]. Although some recent studies have discovered some level of greening in the Sahel proving attributed to management, migration, among others [12], desertification is expected to get worse in Nigeria with the growing population and climate change [9] [20].

\subsection{Soil Properties at Hotspots}

Results show that SOC is generally low in the study area and that SOC is higher in the improved vegetation than in the degraded areas. SOC is directly related to the amount of Soil Organic Matter (SOM) supplied to the soil [36] and this is related to the quantity and quality of the SOM as well as the environmental condition [37] [38]. The area is generally plagued by overgrazing, bush burning, fuel-wood extraction, near total removal of crop residue, naturally low vegetation cover, rapid mineralization due to high temperature and moisture conditions, intensive cultivation, among others [29] [39]-[41] such that even the forest reserves have become scrubby. All these potentially reduced the vegetation biomass and the addition of SOM to the soil.SOM improves the physical properties of soil, increases the Cation Exchange Capacity (CEC) and water-holding capacity of sandy soil, and it contributes to the structural stability of clay soils by helping to bind particles into aggregates [42]-[46]. Conversely, unfriendly agricultural practices impact negatively on the terrestrial capability to sequester $\mathrm{CO}_{2}$ [47].

Further, results show that the general texture in the degraded class is sand, while texture varies between Sandy clay loam and loamy sand in the green areas, suggesting a mutual relationship between SOC and texture. Although the study area is characteristically sandy in nature consequent upon aeolian deposition, the loamy sand and sandy clay loam in the green areas is due to the enrichment from the soil organic matter which in turn is a function of vegetation improvement.

Studies have demonstrated soil textural changes in similar semi-arid environments [48] [49]. Different LULC types reportedly have different effects on textural change through erosion prevention [50]. This is plausible in a vegetated environment such as the green areas in this study. Soil texture is an important physical characteristic of soil which has great significance in land use management [51]. Soils dominated by sand particles drain water very quickly but have lower fertility [38] [52], and this is where the soil of the study area belongs.

\section{Conclusion and Recommendations}

Based on the findings of this study, it is concluded here that the study area is getting dersertified and this has effect on the SOC and texture quality of the study area. Critical factors for soil property improvement in the desert area include increases in aboveground and belowground biomass through vegetation restoration with attendant improvements in soil chemical and physical properties and soil organic matter contents [53]. Thus, it is recommended that government should embark on an afforestation drive to take care of the non-forested areas. Grazing reserves should be established to curtail wanton destruction of vegetation. Alternative fuel such as kerosene and 
cooking gas should be made available at the rural areas and at affordable prices as this will reduce dependence on wood for fuel. Farmers should be taught environment friendly practices for ecosystem sustainability, as this will help preserve the extant forest reserves.

\section{Acknowledgements}

The authors are grateful to the VITO, Belgium for making this data free for this study.

\section{References}

[1] UNCCD (1994) United Nations Convention to Combat Desertification in Countries Experiencing Serious Drought and/ or Desertification, Particularly in Africa. A/AC.241/27, Paris.

[2] Dregne, H.E. (2002) Land Degradation in the Drylands. Arid Land Research and Management, 16, 99-132. http://dx.doi.org/10.1080/153249802317304422

[3] Ravi, S., Breshears, D.D., Huxman, T.E. and D’Odorico, D. (2010) Land Degradation in Drylands: Interactions among Hydrologic-Aeolian Erosion and Vegetation Dynamics. Geomorphology, 116, 236-245.

http://dx.doi.org/10.1016/j.geomorph.2009.11.023

[4] Tewari, V.P. and Arya, R. (2005) Degradation of Arid Rangelands in Thar Desert, India: A Review. Arid Land Research and Management, 19, 1-12. http://dx.doi.org/10.1080/15324980590887056

[5] D’Odorico, P., Bhattachan, A., Davis, K.F., Ravi, S. and Runyan, C.W. (2012) Global Desertification: Drivers and Feedbacks. Advances in Water Resources, 51, 326-344. http://dx.doi.org/10.1016/j.advwatres.2012.01.013

[6] Herrmann, S.M., Anyamba, A. and Tucker, C.J. (2005) Recent Trends in Vegetation Dynamics in the African Sahel and Their Relationship to Climate. Global Environmental Change, 15, 394-404. http://dx.doi.org/10.1016/j.gloenvcha.2005.08.004

[7] Reij, C., Tappan, G. and Belemvire, A. (2005) Changing Land Management Practices and Vegetation on the Central Plateau of Burkina Faso (1968-2002). Journal of Arid Environments, 63, 642-659. http://dx.doi.org/10.1016/j.jaridenv.2005.03.010

[8] Onyewotu, L.O.Z., Stigter, C.J., Abdullahi, A.M., Ariyo, J.A., Oladipo, E.O. and Owonubi, J.J. (2003) Reclamation of Desertified Farmlands and Consequences for Its Farmers in Semiarid Northern Nigeria: A Case Study of Yambawa Rehabilitation Scheme. Arid Land Research and Management, 17, 85-101. http://dx.doi.org/10.1080/15324980301590

[9] Medugu, N.I. (2009) Nigeria and the Advancing Desert. Environmental Synergy. World Press.com.

[10] Wessels, K.J., Prince, S.D. and Reshef, I. (2008) Mapping Land Degradation by Comparison of Vegetation Production to Spatially Derived Estimates of Potential Production. Journal of Arid Environments, 72, 1940-1949. http://dx.doi.org/10.1016/j.jaridenv.2008.05.011

[11] Wessels, K.J., Prince, S.D., Malherbeb, J., Small, J., Frost, P.E. and VanZyl, D. (2007) Can Human-Induced Land Degradation Be Distinguished from the Effects of Rainfall Variability? A Case Study in South Africa. Journal of Arid Environments, 68, 271-297. http://dx.doi.org/10.1016/j.jaridenv.2006.05.015

[12] Olsson, L., Eklundh and LArdo, J. (2005) A Recent Greening of the Sahel-Trends, Patterns and Potential Causes. Journal of Arid Environments, 63, 556-566. http://dx.doi.org/10.1016/j.jaridenv.2005.03.008

[13] Mainguet, M. and Da Silva, G.G. (1998) Desertification and Dryland Development: What Can Be Done? Land Degradation and Development, 9, 375-382. http://dx.doi.org/10.1002/(SICI)1099-145X(199809/10)9:5<375::AID-LDR304>3.0.CO;2-2

[14] Prince, S.D., Becker-Reshef, I. and Rishmawi, K. (2009) Detection and Mapping of Long-Term Land Degradation Using Local Net Production Scaling: Application to Zimbabwe. Remote Sensing of Environment, 113, 1046-1057. http://dx.doi.org/10.1016/j.rse.2009.01.016

[15] El-Hassan, I.M. (2004) Desertification Monitoring Using Remote Sensing Technology. International Conference on Water Resources \& Arid Environment.

[16] Mueller, E.N., Wainwright, J. and Parsons, A.J. (2007) The Stability of Vegetation Boundaries and the Propagation of Desertification in the American Southwest: A Modeling Approach. Ecological Modelling, 208, 91-101. http://dx.doi.org/10.1016/j.ecolmodel.2007.04.010

[17] Kogan, F.N. (2000) Operational Space Technology for Global Vegetation Assessment. Bulletin of the American Meteorological Society, 82, 1949-1964. http://dx.doi.org/10.1175/1520-0477(2001)082<1949:OSTFGV>2.3.CO;2

[18] Omuto, C.T. (2010) A New Approach for Using Time-Series Remote Sensing Images to Detect Changes in Vegetation Cover and Composition in Drylands: A Case Study of Eastern Kenya. International Journal of Remote Sensing, 32, 6025-6045. http://dx.doi.org/10.1080/01431161.2010.499384 
[19] Yelwa, S.A. and Eniolorunda, N.B. (2012) Simulating the Movement of Desertification in Sokoto and Its Environs, Nigeria Using 1km SPOT-NDVI Data. Environmental Research Journal, 6, 175-181. http://dx.doi.org/10.3923/erj.2012.175.181

[20] Odjugo, P.A.O. (2010) General Overview of Climate Change Impacts in Nigeria. Journal of Human Ecology, 29, 4755.

[21] Umar, A.T. (2013) Evidence of Climate Change. In: Iliya, M.A. and Fada, A.G., Eds., The Impact of Climate Change on Sokoto State, Nigeria: Evidence and Challenges, UNDP/Sokoto State Government.

[22] Bijay, S., Charles, O. and Preeti, M. (2009) Multi-Sensor \& Temporal Data Fusion for Cloud-Free Vegetation Index Composites. In: Milisavljević, N., Ed., Sensor and Data Fusion, I-Tech, Vienna.

[23] Eastman, J.R. (2007) Explorations in Geographic Information Systems Technology: Change and Time Series Analysis. Vol. 1, Second Edition, Clark Labs for Cartographic Technology and Geographic Analysis, Clark University, Worcester.

[24] Eastman, J.R. (2009) IDRISI Taiga Guide to GIS and Image Processing. Clark Labs for Cartographic Technology and Geographic Analysis, Clark University, Worcester.

[25] Hutcheson, G.D. (2011) Ordinary Least-Squares Regression. In: Moutinho, L. and Hutcheson, G.D., The SAGE Dictionary of Quantitative Management Research, SAGE Publications, Thousand Oaks, 224-228. http://dx.doi.org/10.4135/9781446251119.n67

[26] Flores, J.P. and Tracy, B. (2012) Impact of Winter Hay Feeding on Pasture Soils and Plants. Agriculture, Ecosystems and Environment, 149, 30-36. http://dx.doi.org/10.1016/j.agee.2011.12.009

[27] Yuksek, T., Gol, C., Yuksek, F. and Yuksel, E.E. (2009) The Effects of Land Use Changes on Soil Properties: The Conversion of Alder Coppice to Tea Plantations in the Humid Norhtern Blacksea Region. African Journal of Agricultural Research, 4, 665-674.

[28] Pennock, D., Yates, T. and Braidek, J. (2006) Soil Sampling Design. In: Carter, M.R. and Gregorich, E.G., Eds., Soil Sampling and Methods of Analysis, 2nd Edition, Taylor and Francis Group LLC, London.

[29] Noma, S.S. and Yakubu, M. (2002) Properties and Classification of Soils in the Main Campus of Usmanu Danfodiyo University, Sokoto, Nigeria. Journal of Agriculture and Environment, 3, 155-166.

[30] Noma, S.S., Tanko, I.I., Yakubu, M., Dikko, A.U., Abdullahi, A.A. and Audu, M. (2011) Variability in the Physic-Chemical Properties of the Soils of Dundaye District, Sokoto State, Nigeria. Proceeding of 35th Annual Conference of Soil Science Society of Nigeria, Federal University of Technology, Minna, 7-11 March 2011.

[31] Omar, G. (2011) Assessment of the Fertility Status of some Irrigated Fluvisols in Northern Guinea Savannah of Nigeria. Savanna Journal of Agriculture, 6, 19-31.

[32] Davies, T. and Fearn, T. (2004) Back to Basics: The Principles of Principal Component Analysis. Spectroscopy Europe, 16, 20-23.

[33] Shlens, J. (2005) A Tutorial on Principal Component Analysis. http://www.cs.cmu.edu/ elaw/papers/pca.pdf

[34] Baisantry, M., Negi, D.S. and Manocha, O.P. (2012) Change Vector Analysis Using Enhanced PCA and Inverse Triangular Function-Based Thresholding. Defence Science Journal, 62, 236-242. http://dx.doi.org/10.14429/dsj.62.1072

[35] Yelwa, S.A. (2008) Broadscale Vegetation Change Assessment across Nigeria from Coarse Spatial and High Temporal Resolution AVHRR Data. Cuvillier Verlag, Gottingen.

[36] Chen, J., Ding, Y. and Hu, Y. (2012) Impacts of Soil Organic Matter and Temperature on Sorption of Acetazolamide on Four Soils. International Journal of Soil and Sediment Contamination, 21, 498-509. http://dx.doi.org/10.1080/15320383.2012.664188

[37] Babalola, T.S., Oso, T. Fasina, A.S. and Godonu, K. (2011) Land Evaluation Studies of Two Wetland Soils in Nigeria. International Research Journal of Agricultural Science and Soil Science, 1, 193-204.

[38] Brady, N.C. and Weil, R.C. (2013) The Nature and Properties of Soil. 14th Edition, Dorling Kindersley, India.

[39] Ibrahim, Z.T. (2011) Soil-Landform Relationship in Sokoto-Rima Floodplains at Sokoto, Nigeria. Unpublished MSc Dissertation, Department of Soil Science, Usmanu Danfodiyo University, Sokoto.

[40] Noma, S.S., Ojanuga, A.G., Ibrahim, S.A., Iliya, M.A. and Yakubu, M. (2008) Characteristics of Soil Influenced by Alternating Wetting and Drying Conditions in Sokoto-Rima Floodplains, Nigeria. Techno Science Africana Journal, 28, 162-167.

[41] Yakubu, M., Abdullahi, I, Ibrahim, B. and Noma, S.S. (2008) Characterization of Upland and Floodplain Soils for Management Implications in Dundaye District, Sokoto, Nigeria. Proceeding of the 32nd Annual Conference of Soil Science Society of Nigeria, Federal University of Technology, Yola, 44-63.

[42] Barbera, V., Poma, I., Gristina, L., Novara, A. and Egli, M. (2012) Long-Term Cropping Systems and Tillage Man- 
agement Effects on Soil Organic Carbon Stock and Steady State Level of C Sequestration Rates in a Semiarid Environment. Land Degradation and Development, 23, 82-91. http://dx.doi.org/10.1002/ldr.1055

[43] Leeper, G.W. and Uren, N.C. (1993) Soil Science, an Introduction. 5th Edition, Melbourne University Press, Melbourne.

[44] McCauley, A., Jones, C. and Jacobsen, J. (2005) Soil and Water Management: Basic Soil Properties. Montana State University Extension Services, Montana State University, Bozeman, 994-2721.

[45] McCauley, A., Jones, C. and Jacobsen, J. (2009) Commercial Fertilizers and Soil Amendments. Montana State University Extension Services, Montana State University, Bozeman, 994-5132.

[46] Yang, H., Yuan, Y., Zhang, Q., Tang, J., Liu, Y. and Chen, X. (2011) Changes in Soil Carbon, Total Nitrogen, and Abundance of Arbuscular Mycorrhizal Fungi along a Large-Scale Aridity Gradient. Catena, 87, 70-77. http://dx.doi.org/10.1016/j.catena.2011.05.009

[47] Alvaro-Fuentesa, J., Easter, M., Cantero-Martinez, C. and Paustian, K. (2011) Modelling Soil Organic Carbon Stocks and Their Changes in the Northeast of Spain. European Journal of Soil Science, 62, 685-695. http://dx.doi.org/10.1111/j.1365-2389.2011.01390.x

[48] Abdulrashid, L. and Mashi, S.A. (2014) Soil Degradation in Marginal Areas: Perspectives of Farming Communities of Semi-Arid Areas of Katsina State, Northern Nigeria. International Journal of Innovative Research and Development, 3 , 449-460.

[49] Abdulrashid, L. and Yaro, A. (2014) Local Theories on Soil Formation and Classifications by Farming Communities of Semi-Arid Areas of Katsina State, Nigeria. Journal of Environment and Earth Science, 4, 65-67.

[50] Oruk, O.E., Eric, J.N. and Ogogo, A.U. (2012) Influence of Soil Textural Properties and Land Use Cover Type on Soil Erosion of a Characteristic Ultisols in Betem, Cross River Sate, Nigeria. Journal of Sustainable Development, 5, 104 -110. http://dx.doi.org/10.5539/jsd.v5n7p104

[51] Mohamed, M.Y. and Abdo, B.M. (2011) Spatial Variability of Some Soil Properties in El-Multagha Agricultural Project (Sudan) Using Geographic Information Systems (GIS) Techniques. Journal of Soil Science and Environmental Management, 2, 58-65.

[52] King, C. (2009) Soil. Microsoft Encarta, Microsoft Corporation, Redmond.

[53] Qi, Y., Yang, F., Shukla, M.K., Pu, J., Chang, Q. and Chu, W. (2015) Desert Soil Properties after Thirty Years of Vegetation Restoration in Northern Shaanxi Province of China. Arid Land Research and Management, 29, 454-472. http://dx.doi.org/10.1080/15324982.2015.1030799

\section{Submit or recommend next manuscript to SCIRP and we will provide best service for you:}

Accepting pre-submission inquiries through Email, Facebook, Linkedin, Twitter, etc

A wide selection of journals (inclusive of 9 subjects, more than 200 journals)

Providing a 24-hour high-quality service

User-friendly online submission system

Fair and swift peer-review system

Efficient typesetting and proofreading procedure

Display of the result of downloads and visits, as well as the number of cited articles

Maximum dissemination of your research work

Submit your manuscript at: http://papersubmission.scirp.org/ 